\title{
The Australian and New Zealand Association Jubilee Meeting
}

\begin{abstract}
THE jubilee meeting of the Australian and New Zealand Association for the Advancement of Science, founded on the model of the British Association, has just ended after a most successful week of addresses and discussions at Canberra (January 11-18). It is the first time that the Association has met at the capital city of Canberra, and the meeting was probably unique by reason of the high ratio of visiting men of science to local members. Usually the meetings take place every two years at the big Australian and New Zealand cities in turn, where the visitors are lost in the large populations. Canberra is still a small garden city, and the problem of housing more than a thousand visitors was no small one.
\end{abstract}

The Australasian Association follows the British model very closely; but there are sixteen sections altogether. The president for the meeting was Prof. Emest Scott, who delivered an address on the "History of Australian Science". The sectional presidential addresses included: Section A (Astronomy, Mathematics and Physics), "Physical Quantities", by Prof. T. Parnell; Section B (Chemistry), "The Atmosphere as a Raw Material", by W. Russell Grimwade; Section C (Geology), "Some Aspects of Glaciation in Now Zealand", by Prof. R. Speight; Section D (Zoology), "The Role of Zoology in the Field of Modern Biology", by Prof. E. J. Goddard; Section E (History), "The Study of History: A Synoptic View", by Prof. R. M. Crawford ; Section F (Anthropology), "Anthropology in Australia", by Prof. A. P. Elkin; Section G (Economics, Statistics and Șocial Science), "The Place of Expectations in Economic Theory", by L. G. Melville; Section $\mathrm{H}$ (Engineering and Architecture), "The Use and Convenience of Man", by Sir Henry Barraclough; Section I (Medical Science), "Physical Education in Relation to National Fitness", by Dr. E. Sydney Morris; Section J (Education, Psychology, and Philosophy), "Growing Up", by J. R. Darling; Section K (Agriculture and Forestry), "Some Aspects of Plant Pathology", by Dr. W. L. Waterhouse; Section L (Veterinary Science), "Some Modern Trends in the Study of Host-Parasite Relationships in Animal Disease", by Dr. L. B. Bull ; Section M. (Botany), "The Plant in Relation to Water", by Prof. J. G. Wood ; Section N (Physiology), "The Protein Molecule", by Prof. W. J. Young; Section O (Pharmaceutical Science), "Some Aspects of Fifty Years Progress in Pharmaceutical Science", by Dr. E. M. Watson ; Section P (Geography), "The Present Status of the Geographical Knowledge of New Guinea", by G. A. V. Stanley.

Among the more important discussions and symposia of the meeting was one on "Radio Research" (Sections $\mathbf{A}$ and $\mathbf{H}$ ). A considerable liveliness in radio research is noticeable in Australia, one especially important field being the investigation of the ionosphere. Closely associated is the work of the Commonwealth Solar Observatory at Mount Stromlo, and considerable attention has been paid to the relationship between solar eruptions and radio fadeouts. Sections $\mathrm{P}$ and $\mathrm{K}$ enjoyed an excellent discussion on "Soil Erosion", a subject now of importance in Australia. This was introduced by a paper by Sir John Russell, a guest from England.
The subject was tackled from practically every point of view : pastoral, soil chemistry, and geographical and forestry aspects also came into the picture.

Another well-developed discussion in which the Botanical, Physiological and Medical and Veterinary Sections were engaged, with representatives from the Chemistry Section, covered the subject of "Virus Diseases". Needless to say, no definite conclusions were reached as to the nature of viruses (living or non-living). They were accepted as particulate, and as consisting of nucleo-proteins. One view put forward claimed them as specialized derivatives (reduction forms) of bacteria. The chemists arranged symposia on "Colloids", and on "Organic Nitrogen Compounds".

A well-attended meeting of agriculturists held a symposium on the "Pasture Problems of Australia", and the Zoology Section, for the first time in Australia, had a day devoted to "Marine Biology and Fisheries", at which several interesting original papers were read. The Zoology Section also discussed the important problem of conservation of the native fauna of Australia, and resolutions were passed which are noted below.

The geologists held five symposia : "Metasomatism of Country Rock near Ore Bodies"; "Sub-divisions of the Lower Palæozoics in East Australia" ; "The Permian Sequence in Australia" ; and "Granitisation in Australia", being four of them.

It is impossible to indicate all the good work at the sections. The list of original papers shows a sustained rise in the results of research of a high standard, much of which has great economic value. Almost three hundred papers were listed for presentation at this meeting.

One of the most important meetings was a discussion covering all sections, the subject being "The Relation of Science to Society". It was opened by Sir David Rivett. This and many of the other discussions and presidential addresses were attended by the Governor-General, Lord Gowrie. The result of the discussion, at which references were made to the new activities of the British Association and of the American Association, was the formulation of several resolutions and the direction for the establishment of a committee to consider the whole subject. One recommendation was to the effect that: "In conjunction with the British and American Associations for the Advancement of Science, we wish to affirm our loyalty to the task of preserving truth, freedom of expression, and justice to the world. These are to-day subject to increasing attacks, which if successful will frustrate the future of Science and Humanity, which require that the labours of the Scientist must be utilised for the benefit and not the destruction of mankind."

Section A asked the Association to associate itself with a movement towards calendar reform.

The anthropologists asked the Association to urge the Australian Governments for funds to support the continuance of anthropological research now that the Rockefeller grants have been exhausted.

One of the most important recommendations adopted was a request from Section D, that all the Australian States should be warned of the importance 
of establishing national reserves for the maintenance of the natural fauna and flora, and that these should be set up in more secluded areas and controlled and administered by experts. A request was also made for the beginning of a biological survey of Australia.

Excitement was lent to the proceedings of the Congress by two stimulating lectures given by $\mathrm{Mr}$. H. G. Wells, who had been invited specially to Australia for the meeting. Mr. Wells was provocative, especially with his paper on "The Poison called History" which was delivered to the History Section; but attended by a great crowd, and much appreciated.
Other visitors specially invited from England were Sir John Flett, Sir John Russell, Prof. F. T. Brooks and Prof. N. V. Sidgwick. Prof. Brooks gave a lecture on "Epidemic Plant Diseases" and Prof. Sidgwick read a paper bearing the title "Multiple Links". Another visitor from England, Sir George Simpson, read a paper on "Electricity in Thunder Clouds" to Section A, and delivered a public lecture on "Iee Ages".

The Congress was an unqualified success, despite the terrific heat $\left(109^{\circ}\right.$ in the shade one day), all records for Canberra being broken. W. J. DAKIN.

\section{The Underground Water of London}

\begin{abstract}
$A \mathrm{~N}$ excellent and serviceable memoir on "The A Water Supply of the County of London from Underground Sources", prepared by Dr. Stevenson Buchan, has been issued by the Department of Scientific and Industrial Research (H.M. Stationery Office. $6 s .0 d$. net). It is primarily a supplementary development of the "Records of London Wells" by Messrs. Barrow and Wills, published by the Geological Survey in 1913, restricted in purview to the county boundaries and brought up to date by means of the later accumulation of information. Records of 1,080 wells are set out in detail, of which 565 make their appearance for the first time. More than one hundred of the records of strata are fully described, the remainder being in abstract form.
\end{abstract}

The memoir is commendably complete, for it gives a résumé of the history of London's water supply, with many interesting facts about the early and primitive sourees from which it was drawn. So far back as 1236 , water was brought to the City through conduits from wells and springs outside the populated area. Tyburn, Paddington, Hackney and Hampstead all contributed their quota during the period 12361549. In 1582, water was obtained from the Thames by a pump actuated by water wheels located at London Bridge. Then in 1613, the new river system was inaugurated, bringing supplies from springs in Hertfordshire, because at the beginning of the seventeenth century, the tributary streams through the town had become choked and partly buried, and few of the public wells remained. Towards the end of the eighteenth century, the first deep wells were sunk; but the movement did not make much headway for several years. Water companies were formed about the same period to draw supplies from the Thames and its tributaries, and to store it in reservoirs. These external surface sources now constitute the main feeder system.

As regards the wells, the early shallow borings were sunk to the sand and gravel terraces on the river banks. When, in course of time, these became polluted, deeper borings were made through the London Clay to the strata known as the Reading Beds and Thanet Sands, containing water either percolating from surface outcrops outside London or derived from the underlying chalk, which, acting as an enormous reservoir, to-day is the most important water-bearing bed under London. The water-level, however, is falling both in the sands (some supplies are actually exhausted in the northern area) and in the chalk, whence water is being extracted more rapidly than the rate of replenishment by the extremely slow flow which is alone possible under existing subterranean conditions.

As examples, the memoir mentions the wells close to the National Gallery, which, at one time, supplied the fountains in Trafalgar Square, many of the public buildings in Whitehall, the old Millbank Prison and the Houses of Parliament. Between 1844 and 1911, the water-level had fallen $127 \mathrm{ft}$., and the wells were shortly afterwards abandoned. Another well, which used to feed the Serpentine and its fountains, the Palace Lake and the lake in St. James's Park, had its water-level lowered by $96 \mathrm{ft}$. in the space of fortyeight years and was also abandoned.

With the increase in pumping and the growing competition for supplies, the lowering of the waterlevel is becoming more and more pronounced. New wells in the district of ehalk outcrop are tapping quantities of water which might otherwise travel towards the centre of London. Moreover, land drainage over the surface of the outcrop is now more efficient and the quantity of rainfall available for absorption correspondingly diminished, both from this cause and also from the increase in impermeable surface due to building and road making. Finally, the prolonged periods of drought in recent years have exercised their adverse influence in preventing the recovery of lost levels. With the depression in level, there has been manifested an increase in salt water pollution of many wells down river from Bermondsey.

Wells have been sunk below the chalk to the Old Red Sandstone, the deepest of which is a well at Stonebridge Park, with a depth of 2,225 ft. Unfortunately, after encountering traces of oil and gas from levels below 1,500 ft., the final yield was small and distinctly saline.

The following conclusions are drawn as to the future of supplies from the chalk-sand reservoir under the County of London. The fall in water-level is likely to continue and the annual rate of depression to increase. If a uniform, or slightly increased rate of fall be assumed, the water will reach the base of the Upper Chalk in many parts of London during the present generation, and, at this level, it is probable that a negligible amount of water will be obtainable from the wells. There is, moreover, little likelihood of a supplementary supply from the beds below the Chalk under London.

Brysson Cunningham. 